\title{
FLEXIBILITY AND LABOUR MARKET RESTRUCTURING: THE WATERFRONT INDUSTRY
}

\author{
James Reveley \\ Canterbury University
}

It is hardly possible these days to write in a theoretically informed fashion about the restructuring of industry and employment without entering the 'flexibility debate'. The emergence of the flexibility literature in the 1980s ushered in a period in which work and employment practices began to be written about in new and different ways (Piore and Sabel 1984; Shaiken et al. 1986; Hirst et al. 1991). These have both incorporated elements of the Braverman-inspired labour process debate, hitherto the orthodoxy in this area, and have moved far beyond it (Wood 1989). The literature that is associated with the flexibility debate in all of its forms, however, has focused almost exclusively upon manufacturing. This paper seeks to resituate and ground the debates surrounding 'flexibility' by examining a strategically located and recently deregulated service industry. The case that will be dealt with is New Zealand's waterfront industry and the focus will be upon continuity and change in the organization of the labour market in this industry.

A substantial portion of the flexibility literature has sought to analyse the emergence of 'flexibility' within labour markets (Hudson 1989; Marginson 1989; Dey 1989). The British author John Atkinson, whose work is central to the flexibility literature, has developed a model that deals with this process. Atkinson (1984; 1985; 1987), in his 'flexible firm' model, is essentially dealing with the introduction of casual labour into the bureaucratic form of the modern industrial capitalist firm. This development involves renegotiating the boundary between the internal and external labour markets.

The reorganization of labour markets, however, is a both a sector-specific and industry-specific process. Atkinson's model, and indeed all 'abstract models' of this type, are of little use in analysing how labour markets in specific industries are being restructured. Rather than relying on 'clean models' like Atkinson's, such analysis requires a 'dirtying of one's hands' through empirical research (Hirsch, Michaels and Friedman, 1990). To understand changes in the nature of the labour market in the waterfront industry it is necessary to examine how the labour market was organized in practice in this industry both before and after deregulation.

This paper will begin by identifying some of the main features of the industry and their implications for how the employment relationship is constituted, and the specific type of unionism that emerged, on the waterfront. It will then characterize the nature of the labour market that developed within the industry, drawing in a critically selective fashion upon a typology of labour markets developed by Fligstein and Femandez (1988). Finally. the main continuities and discontinuities in the labour market following deregulation will be identified.

\section{Features of the Waterfront Industry}

The unique features of the waterfront industry result from the types of services it provides and its close relationship with the shipping industry. Indeed it is often described as a link in an 'unbroken chain' that connects land transportation and shipping. It is the link with shipping that lends the waterfront industry its intermittent or sporadic nature. The two main services that form the core of the industry are wharfingering (which refers to the movement, arrangement and storage of cargo on wharves) and stevedoring (which refers to the transfer of cargo between ships and wharves). These services are, of course, only provided when ships are actually in port.

Considerable fluctuations in the levels of shipping activity within ports is the norm in the industry throughout the world, and this results in a great deal of variability in the demand for these services. To use a manufacturing metaphor, this leads to a high degree of 'production discontinuity' which in turn results in rapid fluctuations in the demand for labour.

Employers in the waterfront industry have typically used casual labour at one time or another in order to solve the problems of synchronizing the supply of and demand for labour. In fact in some countries the industry has traditionally been totally based on casual labour (Phillips and Whiteside 1985). For instance, such a system existed in Britain until 1967. although it was mitigated in 1947 by the National Dock Labour Scheme (Wilson 1972:88). In most countries, however, the struggles initiated by waterfront unions to decasualize the industry were resolved much earlier. In ports on the West Coast of the United States and in New Zealand this occurred as early as the 1930 s and 1940s.

\section{Unionism on the Waterfront}

In New Zealand, as in other countries, the union (in this 
case the Waterside Workers Union) adopted 'restrictive' strategies (Fligstein et al. 1988:15) in its struggle to shift from a system of casual labour employed on spot contracts topermanent employment. These strategies were based on controlling the supply of labour to stevedoring firms within ports.

The principles of craft unionism, and the organization of industries along craft lines, are always based on union control of the labour supply. ${ }^{1}$ In the waterfront industry, however, the type of strategy adopted by the Waterside Workers Union to establish closure within the local labour market results from the fact that the labour process does not lend itself to closure as readily as it does in craft-based industries such as construction (Stinchcombe 1959; Austrin 1980). Although they are skilled, waterfront workers are, for all intents and purposes, 'skilled labourers'.

Union strategies thus centered on the establishment of registration systems. The union sought to control access to the local labour market, not by controlling access to training and certification in specific sets of skills through such means as union-controlled apprenticeship programs, as is the case in craft industries (Fligstein et al. 1988:17), but rather by controlling access to the bureaucratic procedures which govern registration. Such registration systems were intended to control the supply of labour by limiting employment to registered waterfront workers, thus allowing the union to eliminate or to restrict casual labour, and to establish guarantees of employment and job security (Turnbull et al., 1992:8).

One possible outcome of union struggles for registration, together with the desire by employers for a 'flexible' supply of labour, is the development of specific bureaucratic forms that will henceforth be termed systems of labour administration. These systems are designed to eliminate (through systematic decasualization), or at least manage, casual labour by establishing a bureaucratic buffer between workers and firms. They relieve individual firms of the responsibilities typically associated with the management of labour and confer these onto a specialized and separate institution. Such systems typically regulate the "ports of entry' into the employment relationship, the allocation of employees to jobs, and the distribution of work and remuneration. Broadly speaking, they involve the construction of an 'internal market', which is nonetheless external to firms, and a 'pool' of labour.

These systems of labour administration took a number of different forms in different countries and were usually forged through often bitter and protracted struggles between unions and employers. The common feature of such systems is that an indirect employment relationship is established in the sense that the relationship between waterfront workers and their employers is mediated by a labour bureau, hiring hall or some comparable institution. Waterfront employees thus face their employers 'onceremoved' as it were. The differences in these systems are registered primarily by whether the internal market (the 'pool' of labour) is constituted, organized and 'administered' by the state, by unions or by employers - or some combination thereof. The primary issue is the relative control each party exerts over the supply of labour.

The American solution in the ports of Los Angeles and Long Beach, for instance, was one of decasualization through the development of a hiring hall controlled jointly by the International Longshoremen's and Warehousemen's Union and the employers (Finlay 1988). A system of worker registration was introduced along with procedures to allocate work and earnings on a more equitable basis than occurred under the previous casual system, under which workers are hired on spot-contracts at what has variously been called a 'shape-up' or an 'auction block', a system that is notoriously prone to favouritism and corruption. ${ }^{2}$

\section{New Zealand's 'Bureau System'}

A very different system developed in New Zealand insofar as it was organized centrally by the state. In 1940 a stateregulated national system of worker registration, administered by a series of local port-based labour bureaux, was established thereby systematically decasualizing the industry. The 'bureau system', as it was known, was modified a number of times until it was finally locked in place in 1953, a development that represented one of the most significant outcomes of the crisis on the waterfront in 1951.

The shift to a national bureau system organized and administered by the state was accompanied by the establishment of a series of institutions to take the place of the Arbitration Court. This ultimately took the form of an institution called the Waterfront Industry Tribunal, which was responsible for setting Principal Orders (the equivalent of national awards), and local Port Conciliation Committees.

The Waterfront Industry Commission introduced a peculiar set of arrangements onto the waterfront in that watersiders were organized independently of employers by the bureau but were, in a sense, still 'employed' by them. Gangs of watersiders were retained from the bureau by stevedoring companies and shipping companies for the duration of a job only. Employers were eligible to retain labour from the bureau only if they too were 'registered' under the system. Workers on the bureau register were entitled to guaranteed wages (in the form of daily and weekly minimum payments) and preference of employment. The Waterfront Industry Commission paid all wages and bonuses but the actual costs of labour incurred when watersiders were 'employed' on a job were recovered by the Commission charging the companies in question. The Commission's administration costs and the guaranteed wages and 'attendance money' paid to watersiders were all funded by a national levy on employers. Thus, in a sense, the state 'nationalized' labour by means of this levy. The end result was a state-guaranteed system of labour contracting. 


\section{Firm Control Over Demand \\ (Firm Size Relative to the Labour Market)}

Large Small

\author{
Worker-Control \\ over supply
}

Organized

Degree of Worker organisation

Unorganized
Worker-Firm Worker-

Negotiated Controlled

Firm-Internal Competitive

Source: Fligstein et al. 1988: 16

\section{The Nature of the Labour Market Under the Bureau System}

In a contribution to the emergent field that Fevre (1992) has recently termed the 'sociology of labour markets' Fligstein et al. (1988) present a typology of labour markets that is of some use in characterizing the type of labour market that developed in the waterfront industry during the era of the 'bureau system'. The model identifies four types of labour markets that may develop in the context of different sets of resources held by workers and firms. The crucial variables are: (1) firm size in relation to the labour market and (2) the level of control by unions over the supply of labour, which is assumed to correspond to a higher or lower degree of worker organization (ibid:16).

The first of these types of labour markets is characterized by large firms and a high degree of worker control of the labour supply. These features equate with worker-firm negotiated (or 'contested') labour markets in which collective bargaining is the norm. Such markets exist in industries in the manufacturing sector. In the second case, large firms and unorganized workers correspond to the development of firm-internal labour markets. In the third, small firms and unorganized workers result in the development of 'competitive' labour markets. Finally, small firms and a high degree of union control of the labour supply produce 'worker controlled' labour markets. Examples of the latter are found primarily in craft-based industries such as construction.

The applicability of this model to the waterfront industry is limited in two crucial respects. The first relates to the organization of the industry itself which renders firm size relatively unimportant. The horizontal axis of the diagram which relates to firm size can largely be ignored because the bureau system effectively eliminated competition within the labour market. Firms did not compete with each other for labour because the state guaranteed a supply of labour. Small independent firms (such as the Lyttelton Stevedoring
Company) existed alongside large firms (such as Union Maritime Services) that were vertically integrated for reasons other than securing a supply of labour.

Nonetheless, the waterfront industry possessed may of the features of a 'worker controlled' labour market. However, it was not 'worker controlled' because unions controlled access to training in a specific set of skills, as in the case of the craft unions that Fligstein et al. (1988) cite, but rather because of the existence of a bureaucratic buffer between watersiders and their employers that established a registration system that the union controlled access to. Union membership was a prerequisite for having one's name placed on the bureau register and prospective watersiders, in a sense, had to 'apply' to the union for a job. Under this system, the union controlled access to a waiting list rather than to a set of skills. To put it differently, the union effected closure within the local labour market by regulating entry to positions within a queue (Murphy 1988:249).

The second limitation of the model inheres in the assumptions that inform it. Fligstein et al's model assumes that union control of the labour supply automatically and unambiguously corresponds to control over work practices (or 'job control'). To be sure, under the bureau system the degree of control that the Waterside Workers Union exerted over the labour supply did indeed have its concomitant in a high degree of job control in a manner that emulated craft unionism.

Under the bureau system, the union strategy of job control centered on union enforcement of comprehensive and detailed work rules encoded in the legally enforceable General Principal Order, coupled with frequent appeals to the local Port Conciliation Committees. The high degree of workplace organization of the union and well-developed delegate structure operated to systematically 'police' these rules. Examples of the degree of job control exerted by the union on the waterfront are the rigid lines of demarcation 
that the industry was notorious for. Indulgency patterns such as 'spelling' (whereby only half of each gang would work at any one time) also testify to the union's degree of job control.

However, it is the uncoupling of the link between union control of the labour supply and union control of work practices that has been the most significant outcome in the waterfront industry of the deregulation of the labour market. Indeed this is the key to 'labour flexibility' on the waterfront.

\section{Continuities and Discontinuities in the Labour Market Following Deregulation}

The bureau system survived, with amendments, until 1989 when it was abolished by the Waterfront Industry Reform Act. This has resulted in firms again becoming the organizational form which employs and manages labour on the waterfront. This development, together with the bargaining regime established by the Employment Contracts Act, has posed fundamental challenges to the Waterside Workers Union.

The most serious of these has been to prevent the use of non-union labour on the waterfront. Thus far has been able to do so. Not only has a union presence been retained on the waterfront, the union still exerts a degree of control over the supply of labour in the sense that all waterfront workers (including casuals) must belong to the union. The union also acts as their bargaining agent in negotiations. It has also been able to limit the use of casual labour. At Lyttelton, for instance, the union has restricted firms' use of casuals to $25 \%$ of permanent workers.

The union's retention of its presence on the waterfront and the ability to limit the use of labour to union labour is its strength at the moment. This modicum of control over the type of labour that is 'supplied' is the fundamental continuity between the regulated and deregulated systems. Given the potential for employers to use non-Waterfront union labour afforded by the Employment Contracts Act (Boxall 1991), why has this in fact not occurred?

First, it is a result of the strength of the union which existed under the previous system. Union strategies based on controlling the supply of labour, and the support lent to them by the bureau system, have placed the union in a position that has enabled it to resist some of the encroachments upon it by employers using tactics sanctioned by the Employment Contracts Act.

The very success of the bureau system, from the union's point of view, under which it gained considerable control over the supply of labour, has set limits upon what can be achieved by employers within the current deregulated system. Furthermore, it is not possible for stevedoring firms to relocate operations to greenfield sites because ports, by their very nature, are spatially fixed. For this reason, firms have had to restructure their operations using labour that is already well-organized. All attempts to restructure the industry therefore come up against the barrier of organized labour.

It is the case, however, that stevedoring companies are actually prepared to tolerate a union presence on the waterfront in the climate created by the Employment Contracts Act, insofar as it has weakened the union's control over workplace practices. To date only one new entrant firm, an Auckland-based company called Aotearoa Stevedoring, has attempted to use non-Watersiders' Union labour. Even this was something of an exceptional case in that it had an ethnic dimension to it. In any case the company has not been able to assemble a workforce that it can use on the waterfront. This testifies even further to the degree of informal control of the labour supply currently wielded by the union.

The fundamental discontinuity between the regulated system and the deregulated system is that under the current bargaining regime the union has lost a considerable degree of its control of the workplace. In their push for productivity increases, the employers have eroded the union's degree of job control through enterprise bargaining. A sign of this is the end to all demarcation disputes. Other signs include the erosion of task boundaries, the emergence of multi-tasking, more 'flexible' working hours, and significant reductions in gang sizes and in manning generally. This development is also the key to the massive productivity increases within ports that have been achieved in the context of considerable reductions in manning. For instance, productivity increases of as much as $150 \%$ in the loading of logs have been reported in the Port of Tauranga despite a reduction in gang sizes by almost one half (Trebeck 1990:5).

It is apparent, however, that the union has not totally lost control of work practices. Paradoxically, the union's vehement resistance to the non-union labour used by Aotearoa Stevedoring indicates this. The main reason that the union is seeking to restrict the supply of labour to union members is that it, quite understandably, fears that work practices will be modified even further if new entrant firms using non-union labour are allowed onto the waterfront.

\section{Summary and Conclusions}

The aim of this paper has been to break with the abstract concerns of the flexibility literature regarding labour market 'flexibility' by examining the restructuring of the labour market in a specific industry. it has demonstrated that the waterfront industry's unique characteristics led to the emergence of a type of unionism that focused primarily on controlling the supply of labour within local labour markets. In turn, this resulted in the development of a unique set of practices and institutions through which the employment relationship was constituted. Under this 'bureau system' of labour administration the labour market had all of the hallmarks of a 'worker-controlled' labour market. The deregulation of the labour market, however, has resulted in the erosion of the degree of control held by the union, particularly with respect to workplace practices. 
In conclsuion, it is apparent that in the climate currently created by deregulation there is a need for more industryspecific empirical studies in order to discover how labour markets are being reorganised in practice. This paper has presented the main features of how this process of change is working itself out in New Zealand's ports.

\section{Future Research}

There are three directions that deserve attention.

a. The most important is an examination of the 'other side' of the labour market, i.e. , the nature of the firms in the waterfront industry prior to and following deregulation.

b. Consideration needs to be given to the way that the bureau system of labour administration resulted in the emergence of particular types of firms, a development which, with respect to the organisation of the labour market, effectively rendered firm size a dependent rather than an independent variable.

c. The labour market effects of new types of organisations on the waterfront (port companies in particular) also merit further attention.

\section{Notes}

${ }^{1}$ See, for instance, the study by Hinton (1973) of craft unionism in the engineering industry in Britain.

${ }^{2} \mathrm{~A}$ literary text that describes this system in detail is Budd Schulberg's 'Waterfront'. Existing sociological accounts testify to the verisimility of this work (Pilcher 1972; Mills 1979).

${ }^{3}$ For one of the best accounts of the centrality of job control to craft unionism see Selig Perlman's now classic 'Theory of the Labour Movement'.

\section{References}

Atkinson, J. 1984 Manpower Strategies for Flexible Organisations Personnel Management September: 26-29.

Atkinson, J. 1985 The Changing Corporation New Patterns of Work D. Clutterbuck (ed), Gower, Aldershot: 13-34.

Atkinson, J. 1987 Flexibility or Fragmentation? The United Kingdom Labour Market in the Eighties Labour and Society 12, 1: 87-105.

Austrin, T. 1980 The 'Lump' in the U.K. Construction Industry Capital and Labour: Studies in the Capitalist Process T.Nichols (ed), Athlone Press, London.

Boxall, P. 1991 New Zealand's Employment Contracts Act 1991 Australian Bulletin of Labour 17, 4: 284-309.
Dey, I. 1989 Flexible 'Parts' and Rigid 'Fulls' : The Limited Revolution in Work-Time Patterns Work, Employment and Society 3, 4: 465-490.

Fevre, R. 1992 The Sociology of LabourMarkets Harvester Wheatsheaf, Hamel Hempstead.

Finlay, W.1988 Work on the Waterfront Temple University Press, Philadelphia.

Fligstein, N. and R. Fernandez 1988 Worker Power, Firm Power and the Structure of Labour Markets The Sociological Quarterly 29, 1: 5-28.

Hinton, J. 1973 The First Shop Stewards' Movement Allen and Unwin, London.

Hirsch, P., S. Michaels and R. Friedman 1990 Clean models vs dirty hands: why economics is difference from sociology Structure of capital: the social organisation of the economy S. Zukin and P. DiMaggio (eds) Cambridge University Press, Cambridge

Hirst, P. and J. Zeitlin 1991 Flexible Specialisation versus post-Fordism: Theory, Evidence and Policy Implications Economy and Society 20, 1 : 1-56.

Hudson, R. 1989 Labour-Market Changes and New Forms of Work in Old Industrial Regions Environment and Planning D : Society and Space 7 : 5-30.

Marginson, P. 1989 Employment Flexibility in Large Companies : Change and Continuity Industrial Relations Journal 20, 2 : 101-109.

Mills, H. 1979 The San Francisco Waterfront : The Social Consequences of Industrial Modernisation Case Studies in the Labour Process A. Zimbalist (ed) Monthly Review Press, New York.

Murphy, R. 1988 Social Closure : The Theory of Monopolisation and Exclusion Clarendon Press, Oxford.

Perlman, S. 1949 A Theory of the Labour Movement A.M. Kelley, New York.

Phillips, G. and N. Whiteside 1985 Casual Labour : The unemployment question in the Port Transport Industry 1880-1970 Clarendon Press, Oxford.

Pilcher, W. 1972 The Portland Longshoremen : A Dispersed Urban Community Holt, New York.

Piore, M. and C. Sabel 1984 The Second Industrial Divide : Possibilities for Prosperity Basic Books, New York. 
Schulberg, B. 1956 Waterfront The Bodley Head,London.

Shaiken, H., S. Herzenbergand S. Kuhn 1986The Work Process Under More Flexible Production Industrial Relations 25, 2 : 167-183.

Stinchcombe, A. 1959 Bureaucratic and Craft Administration of Production : A Comparative Study Administrative Science Quarterly 4, 2 : 168-187.

Trebeck, D. 1990 Port Reform in New Zealand NZBR, Auckland.

Turnbull, P., C. Woolisson and J. Kelly 1992 Dock Strike :Conflict and Restructuring in Britain's Ports Ashgate, Aldershot.

Wilson, D. 1971 Dockers : The Impact of Industrial Change Fontana, Great Britain.

Wood, S. 1989 The Transformation of Work? The Transformation of Work? S. Wood (ed), Unwin Hyman, London : 1-43. 